Yuriy Gvozdev, postgraduate

Bila Tserkva National Agrarian University, Bila Tserkva, Ukraine

\title{
Economic Essence and Value of Investments and Investment Activity of Business Entities
}

The purpose of the study is to develop theoretical and methodological provisions for assessing the content of the concept of "investment activity" of business entities.

The study of the foreign and domestic theory of investment activity, the theoretical analysis of the methods of state regulation of the investment process made it possible to determine the range of issues relating to the instruments of the investment mechanism. They can be summarized as follows: means of knowledge and economic categories (as an instrument for understanding the functioning of the investment mechanism and the financial regulation of the activities of investment institutes, as well as the results and means of this knowledge) used in the theory and practice of studying the problems of improving the investment mechanism; institutes that carry out state financial regulation concerning the subjects of investment activity; principles and rules, functions, tasks and types of their production activities; methods and levers of the investment mechanism that are used in the process of state (administrative) and market (economic) regulation of the activity of investment institutes. The category as a broad concept reflects the most general and important properties, signs, connections and relations of objects, phenomena, processes, etc. Summarizing the above, we systematize the most important signs of investment: they can realize many goals - economic (in the form of income generation), management (improving the quality and competitiveness of products, optimizing costs, etc.), non-economic (social, environmental); contribute to the transformation of various resources of economic entities into alternative types of assets; ensure compliance with market laws of demand and supply for investment resources and services; accompanied by risks of capital investment, that is, the probability of expected results for investment purposes; are characterized by uncertainty of the timing of obtaining the achieved effect from the investment, as well as the dependence of the timing of obtaining benefits from the managerial decisions of the investor.

On the basis of the listed properties of investments it can be noted that this is a purposeful investment of capital that is not connected with current consumption and involves the transformation of resources of economic entities from one form to another in order to generate profit, as well as to achieve another economic and noneconomic long-term effect.

investment, capital investments, business entity, activity, financial resources

Е. О. Панченко, асп.

ДВНЗ «Київський національний економічний університет імені Вадима Гетьмана», м. Київ, Україна

\section{Механізми формування інтелектуального капіталу транснаціональних корпорацій}

У статті узагальнено сучасні практики формування та накопичення інтелектуального капіталу у транснаціональних корпораціях. Проаналізовано обсяги та динаміку фінансування транснаціональними корпораціями досліджень і розробок. Обгрунтовано, що існує два ключові механізми залучення інтелектуального капіталу - формування власного та залучення із зовнішніх джерел, які більшість транснаціональних корпорацій використовують для максимально ефективного накопичення інтелектуального капіталу та його використання. Висвітлено існуючі механізми спільної участі корпорацій в наукових дослідженнях, обсяги торгівлі результатами інтелектуальної діяльності.

інтелектуальний капітал, транснаціональна корпорація, дослідження і розробки (ДіР), роялті, патенти, ноу-хау

Е. О. Панченко, асп.

ГВУЗ «Киевский национальный экономический университет имени Вадима Гетьмана», г. Киев, Украина

() Е. О. Панченко, 2018 


\section{Механизмы формирования интеллектуального капитала транснациональных корпораций}

Обобщены современные практики формирования и накопления интеллектуального капитала в транснациональных корпорациях. Проанализированы объемы и динамика финансирования транснациональными корпорациями исследований и разработок. Обосновано, что существует два ключевых механизма привлечения интеллектуального капитала - формирование собственного и заемного из внешних источников, которые большинство транснациональных корпораций используют для максимально эффективного накопления интеллектуального капитала и его использования. Освещены существующие механизмы совместного участия корпораций в научных исследованиях, объемы торговли результатами интеллектуальной деятельности.

интеллектуальный капитал, транснациональная корпорация, исследования и разработки (ИиР), роялти, патенты, ноу-хау

Постановка проблеми. В умовах становлення постіндустріальної парадигми суспільного розвитку ключовим ресурсом стають знання та, відповідно, всі фактори, пов’язані з їх створенням та поширенням. У цьому контексті особливого значення набуває інтелектуальний капітал, що створюється i функціонує в межах підприємницьких структур. У великих транснаціональних корпораціях (ТНК) першочергового значення набувають наукомісткі процеси, пошук і впровадження новітніх виробів, технологій тощо. Зростання ролі інтелектуального капіталу в розвитку транснаціональних корпорацій пояснює збільшення уваги до цієї проблеми в наукових колах.

Аналіз останніх досліджень i публікацій. Проблеми формування та використання інтелектуального капіталу в межах сучасних потужних ТНК $\epsilon$ актуальними в сучасній економічній науці. Вони досліджуються в працях низки вітчизняних та іноземних авторів, серед яких: Д.В. Станіс [9], Б. Лев [15], В.О. Боос [3], Є.Н. Ветрова, Є.В. Коковіна [6], В.Ю. Школа, В.О. Щербаченко [11], А.А. Бикова, М.А. Молодчик [1], А. Пулик [16], Дж. Лаінг, Дж. Дюнн, С. Хагес-Лукас [14] тощо. Незважаючи на велику кількість досліджень в цьому напрямі, не втрачають своєї актуальності проблеми новітніх механізмів накопичення та використання інтелектуального капіталу, які дозволяють ТНК займати лідируючі позиції в глобальному середовищі. Всі ці процеси потребують подальшого дослідження.

Постановка завдання. Метою статті $є$ аналіз та узагальнення сучасних підходів ТНК до формування та накопичення окремих складових інтелектуального капіталу.

Виклад основного матеріалу. На сучасному етапі діяльності транснаціональних компаній вирішальним фактором їх довгострокової конкурентоспроможності, стабільного розвитку $\epsilon$ формування та максимально ефективне використання інтелектуального капіталу.

Виходячи 3 того, що структура інтелектуального капіталу включає в себе людський, структурний та організаційний капітал визначаємо найбільш ефективний та демонстраційний з капіталів - структурний. Структурний капітал корпорації включає в себе патентну активність та діяльність, дослідні роботи, ліцензії, ноу-хау та ін. Сам капітал може бути власним або залученим із зовнішній джерел (купівля, оренда, вільний доступ).

Формування структурного інтелектуального капіталу ТНК на сучасному етапі включає в себе процеси розробки нових технологій і продуктів за допомогою науководослідних та дослідно-конструкторських робіт (НДДКР), досліджень і розробок (development and researches - R\&D), створення міжнародних альянсів в цій сфері між ТНК для реалізації масштабних проектів, а також юридичне оформлення прав на результати такої діяльності за допомогою реєстрації патентів, покупки і продажу ліцензій і ноу-хау, формування патентних і ліцензійних пакетів ТНК. 
Однією 3 сучасних тенденцій розвитку інтелектуального капіталу ТНК $є$ стрибкоподібне зростання витрат провідних компаній світу на проведення досліджень $і$ розробок (R\&D), лідерство в яких перетворюється в домінантну компоненту міжнародної конкурентоспроможності. Зміна пріоритетів у формуванні конкурентних переваг ТНК стало одним з факторів, які зумовлюють постійне зростання витрат міжнародних компаній на дослідження і розробки, причому це стосується практично всіх галузей діяльності ТНК.

Основними центрами проведення досліджень і розробок ТНК є країни СС, США та окремі країни Азії. Так, за результатами 2016 року найвищі витрати бізнес-сектору на наукові роботи спостерігаються у США, Китаї, Японії (табл. 1).

Таблиця 1 - Витрати бізнес-сектору на дослідження та розробки, 2016 р.

\begin{tabular}{|l|c|c|}
\hline \multicolumn{1}{|c|}{ Країна } & Витрати, млн. дол. & Частка від загальних витрат \\
\hline Південна Корея & 57255,4 & $78,2 \%$ \\
\hline Японія & 132584,8 & $77,8 \%$ \\
\hline Китай & 286453,2 & $77,3 \%$ \\
\hline США & 340728,0 & $71,5 \%$ \\
\hline Німеччина & 74286,1 & $67,7 \%$ \\
\hline Великобританія & 28771,7 & $65,1 \%$ \\
\hline Франція & 38675,9 & $63,6 \%$ \\
\hline Росія & 23742,3 & $59,6 \%$ \\
\hline Італія & 16792,1 & $56,7 \%$ \\
\hline Австралія & 13027,6 & $56,3 \%$ \\
\hline Канада & 14711 & $53,2 \%$ \\
\hline
\end{tabular}

Джсерело: розраховано та сформовано автором на основі [13].

Як свідчать дані про витрати корпоративного сектору на дослідні роботи, найвищий рівень витрат належить США, на другому місці знаходиться Китай, проте аналізуючи частку бізнес-сектору в структурі загальних витрат найвищий рівень у Південної Кореї, друге місце займає Японія, частка якої надзвичайно висока - 78,2 та 77,8\% відповідно. Рівень же витрат бізнесу в Китаї становить 77,3\%, що, виходячи із реальних об’ємів інвестування, становить колосальні суми. Варто відмітити, що сукупні витрати компаній США та Китаю (627181,2 млн. дол.) більш ніж на 40\% перевищують витрати інших 8 компаній в ТОП-10. Загалом у всіх країнах, що входять в ТОП-10, рівень корпоративних витрат на наукові дослідження перевищує $50 \%$ від загальної суми витрат, що свідчить про високий рівень залучення бізнесу та тісні зв'язки в структурі «бізнес-наука».

Глобальні ж витрати на дослідження поступово зростають: 3 1,08\% від глобального ВВП в 2001 році до 1,15\% в 2011p. [18]. В 2017 році корпоративні витрати на дослідження та розробки зросли на 3\% порівняно 3 попереднім роком, а основні тенденції розвитку ринку корпоративного інвестування в розробки свідчать, з одного боку, про посилення економічного націоналізму, а 3 іншого, - про тотальну глобалізацію ринку наукових досліджень та розробок. Так, близько 94\% основних глобальних корпорацій проводять свої дослідження за кордоном. Стримуючими факторами цього процесу стають посилення уваги до правил та політики віз, руху робочої сили та правил, що регулюють обмін знаннями та технологіями. Це викликає питання наскільки стабільними є інтегровані глобальні інноваційні мережі, адже 33\% керівників компаній стверджують про наслідки економічного націоналізму для придбання або ж збереження талантів у сфері досліджень та розробок по причині візових чи міграційних обмежень [12]. Так, майже 50\% компаній Північної Америки запланували змінити дослідницькі програми відповідно до зміни зовнішнього 
середовища. За останні роки найбільшими компаніями з точки зору інвестицій в сферу досліджень і розробок (R\&D) стали компанії CША та Свропи (табл. 2).

Серед найбільш ефективних компаній з високим рівнем витрат на дослідження i розробки $(\mathrm{R} \& \mathrm{D})$ переважна більшість компаній з материнським капіталом США. Так, 3 25-ти компаній 15 належать США, 7 компаній з Європейського Союзу і 3 з Азії. За секторальним розподілом ТОП-25 включає 8 компаній фармацевтичного сектору, 6 автомобільних та 5 компаній, що працюють в секторі програмного забезпечення. Серед означених компаній в табл. 2 лише Volkswagen Aktiengesellschaft за період 2016-2017 pp. демонструє зниження витрат, всі інші демонструють стійкий приріст фінансів. Загалом ТОП-10 компаній інвестували в наукові розробки більше 120 млрд. дол.

Таблиця 2 - ТОП-10 компаній за рівнем витрат на дослідження та розробки $(\mathrm{R} \& \mathrm{D})$

\begin{tabular}{|c|c|c|c|c|c|c|c|c|c|}
\hline \multirow[t]{2}{*}{$\begin{array}{l}\text { Mic- } \\
\text { це }\end{array}$} & \multirow[t]{2}{*}{ Компанія } & \multirow[t]{2}{*}{ Країна } & \multirow[t]{2}{*}{$\begin{array}{c}\text { Сфера } \\
\text { діяльності }\end{array}$} & \multicolumn{2}{|c|}{$\begin{array}{c}\text { Витрати на } \\
\text { дослідження і } \\
\text { розробки, } \\
\text { млрд. дол. }\end{array}$} & \multicolumn{2}{|c|}{$\begin{array}{l}\text { Прибуток, } \\
\text { млрд. дол. }\end{array}$} & \multicolumn{2}{|c|}{$\begin{array}{l}\text { Інтенсивність } \\
\text { досліджень і } \\
\text { розробок, \% }\end{array}$} \\
\hline & & & & 2016 & 2017 & 2016 & 2017 & 2016 & 2017 \\
\hline 1 & Amazon.com.Inc. & США & Продажі & 12,5 & 16,1 & 107,0 & 136,0 & 11,7 & 11,8 \\
\hline 2 & Alphabet Inc. & США & $\begin{array}{l}\text { Програмне } \\
\text { забезпечення } \\
\text { та послуги }\end{array}$ & 12,3 & 13,9 & 75,0 & 90,3 & 16,4 & 15,5 \\
\hline 3 & Intel Corporation & США & $\begin{array}{l}\text { Напівпро- } \\
\text { відники }\end{array}$ & 12,1 & 12,7 & 55,4 & 59,4 & 21,9 & 21,5 \\
\hline 4 & $\begin{array}{l}\text { Samsung } \\
\text { Electronics Co., } \\
\text { Ltd. }\end{array}$ & $\begin{array}{l}\text { Південна } \\
\text { Корея }\end{array}$ & $\begin{array}{l}\text { Технології та } \\
\text { обладнання }\end{array}$ & 12,0 & 12,7 & 166,7 & 167,7 & 7,2 & 7,6 \\
\hline 5 & $\begin{array}{l}\text { Volkswagen } \\
\text { Aktiengesellschaft }\end{array}$ & Німеччина & $\begin{array}{l}\text { Автомобілі та } \\
\text { запчастини }\end{array}$ & 12,5 & 12,1 & 255,2 & 229,4 & 5,6 & 5,3 \\
\hline 6 & $\begin{array}{l}\text { Microsoft } \\
\text { Corporation }\end{array}$ & США & $\begin{array}{l}\text { Програмне } \\
\text { забезпечення } \\
\text { та послуги }\end{array}$ & 12,0 & 12,0 & 93,6 & 85,3 & 12,9 & 14,1 \\
\hline 7 & Roche Holding AG & Швейцарія & Фармацевтика & 9,4 & 11,4 & 49,6 & 51,8 & 19,0 & 21,9 \\
\hline 8 & Merk\&Co., Inc & США & Фармацевтика & 6,7 & 10,1 & 39,5 & 39,8 & 17,0 & 25,4 \\
\hline 9 & Apple Inc. & США & $\begin{array}{l}\text { Програмне } \\
\text { забезпечення } \\
\text { та послуги }\end{array}$ & 8,1 & 10,0 & 233,7 & 215,6 & 3,5 & 4,7 \\
\hline & Novar & & Фармацевтика & 9,5 & 9,6 & 50,4 & 49,4 & 18,8 & 19,4 \\
\hline
\end{tabular}

Джерело: розраховано та сформовано автором на основі [17].

Домінуючі позиції на світовому ринку технологій належать ТНК з США, серед інших країн - лідерів можна відзначити країни СС, Китай, Японію, Індію та ін. На сьогоднішній день на ТНК США припадає 40\% світових витрат на розробку новітніх технологій; 38\% патентів на нові технології, отримані в промислово розвинених країнах; 37\% вчених; 35\% світових наукових публікацій. У США працюють 70\% вчених - лауреатів Нобелівської премії; 66\% авторів наукових робіт, які найбільш активно цитуються в світі; у цій країні знаходиться $75 \%$ університетів, які входять в двадцятку кращих закладів вищої освіти світу.

При цьому слід зазначити, що значна частина ТНК не має фінансових, кадрових, дослідницьких або інженерно-технічних можливостей для того, щоб створювати самостійно технології. I як джерело їх залучення розглядають можливість придбання технологій на міжнародному ринку у інших продуцентів. Таким чином, існування значного попиту на сучасні технології, неможливість для більшості ТНК створювати їх самостійно, i, навпаки, наявність у окремих компаній надлишкових технологій, призвела до того, що в світі сформувалася потужна індустрія торгівлі високими технологіями - світовий ринок технологій. 
Нездатність багатьох ТНК проводити самостійно масштабні дослідження i розробки, які вимагають великих фінансових i організаційних ресурсів, а також необхідність в їх обміні і придбанні, призвела до формування міжнародних стратегічних альянсів ТНК у сфері досліджень і розробок.

Чим вище інтенсивність досліджень та розробок в галузі, тим більш значна частина витрат даного напряму спрямовується ТНК на загальні дослідження, в тому числі на створення міжнародних стратегічних альянсів.

Зростання участі в технологічних партнерствах для ТНК є необхідною умовою для збереження їх конкурентних позицій. Важливою в цьому напрямку є співпраця ТНК з університетами і урядовими дослідними організаціями. Причиною збільшення кількості технологічних партнерств між вищими навчальними закладами, урядовими організаціями та корпораціями $є$ те, що три основних учасники таких партнерств знаходять в них значні переваги [2, с. 14].

Для корпорацій це можливість зменшити витрати на центральні лабораторії досліджень і розробок (R\&D). Державні дослідні організації можуть розширити свою місію і виправдати державну підтримку. Для університетів такі партнерства $є$ дуже корисними, оскільки дозволяють підвищити професійний рівень викладачів, рівень навчання студентів і поліпшити матеріальну базу, а також дають можливість студентам і науковим співробітниками отримати сучасні практичні навички.

Значному поширенню міжнародних стратегічних альянсів, як форми нарощування інтелектуального капіталу ТНК, сприяють такі чинники:

- значне збільшення витрат на створення нових продуктів в окремих галузях;

- значний час між початком досліджень і розробок і виведенням на ринок деяких продуктів (від п'яти до десяти років для авіапромисловості, фармацевтики);

- збільшення складності продажу окремих продуктів на закордонних ринках без створення значної частки доданої вартості на цих ринках;

- збільшення необхідності компенсації значних i тривалих витрат на дослідження і розробки за рахунок швидкого і одночасного виведення нового продукту на велику кількість національних ринків.

Результатом проведених досліджень і розробок окремими ТНК або ж їх стратегічними альянсами є отримання компаніями патентів, ноу-хау, які в свою чергу можуть продаватися або ж купуватися за допомогою ліцензійних угод.

Міжнародна торгівля ліцензіями і ноу-хау, як форма передачі технології, поступово стала новим методом розподілу ринків між великими ТНК. Тому останнім часом часто у великих промислових компаніях створюються спеціальні ліцензійні (патентні) відділи, відділення закордонного ліцензування і дочірніми компаніями по зарубіжному ліцензуванню. Ліцензійні відділи великих ТНК виконують такі функції:

- збір і надання інформації технічним, виробничим і економічним службам;

- вивчення торгівлі патентами і ліцензіями;

- виявлення фірм, які цікавляться покупкою ліцензій, і проведення операцій 3 купівлі-продажу;

- забезпечення патентної охорони наукових досягнень своєї компанії [10, с. 26].

Питання ліцензійних угод ТНК і їх ролі в міжнародних економічних відносинах досить докладно розглянуто окремими авторами. Встановлено, що, 3 точки зору трансферу технологій, ліцензування має певні переваги для ТНК приймаючих країн. Зокрема, розміри ліцензійних винагород, як правило, визначаються заздалегідь. Замість постійних виплат дивідендів на прямі іноземні інвестиції, країни, що розвиваються, при укладанні ліцензійної угоди платять винагороду, розмір якої в основному залежить від обсягів продажів компанії, яка придбала ліцензію.

Однак ліцензування, на нашу думку, більш вигідно ліцензіарові, ніж ліцензіату тому, що останній стикається з низкою проблем, які виникають внаслідок: 
- придбання тільки одного технологічного рішення;

діяльності;

обмеженості використання переданих за ліцензією результатів інноваційної

- постійного контролю за комерційною і виробничою діяльністю ліцензіата 3 боку ліцензіара;

- шахрайства при переговорах про ліцензування 3 метою переконати потенційного покупця в цінності ліцензії;

- ускладненості активізації інновацій, оскільки внесення змін до продукту вимагає обов'язкового узгодження з власником ліцензії [7, с. 68].

Разом 3 тим, в ряді випадків для ТНК продаж ліцензій є найбільш вигідною формою трансферу технологій та комерціалізації інтелектуального капіталу. До подібних ситуацій відносяться:

- прагнення збути невикористану технологію;

- проникнення на важкодоступні ринки;

- відсутність надлишкового капіталу і кваліфікованої робочої сили, необхідної для створення філії за кордоном;

- високий політичний ризик інвестицій в окремих країнах, що розвиваються.

Продаж ліцензій має сенс у тому випадку, якщо фірма, яка володіє цінними технологічними ноу-хау або патентами на унікальну продукцію, не має організаційних структур на зарубіжних ринках і ресурсів для самостійного виходу на ринок.

Можна зробити висновки, що політика ТНК в сфері формування інтелектуального капіталу ТНК, торгівлі ліцензіями і ноу-хау на сучасному етапі має такі особливості:

1) продаж ліцензій на початкових етапах життєвого циклу товарів, причому нерідко власним конкурентам, щоб протягом все більш короткого періоду існування ринкового попиту на технічне нововведення встигнути окупити витрати на дослідження і розробки доходами від реалізації результатів;

2) встановлення монопольно високих цін на запатентовану продукцію, обмеження виробництва і випуску нової продукції покупцями ліцензій;

3) придбання блоків патентів, створення патентних пулів;

4) штучне гальмування використання нових винаходів 3 метою розтягування термінів морального старіння реалізованих винаходів;

5) позбавлення дочірніх компаній самостійності у виборі техніки і технології;

6) використання внутрішньо корпоративного обміну технологіями, як засобу зовнішньоекономічної експансії;

7) застосування обмежуваної ділової практики при передачі технології незалежним іноземним компаніям;

8) обмеження на використання технології або ноу-хау після закінчення терміну дії патенту або ліцензії;

9) встановлення умов, які зобов'язують покупця технології передавати продавцеві зроблені ним удосконалення і поліпшення технології;

10) встановлення цін на продукцію, вироблену 3 використанням проданої технології;

11) обмеження обсягів виробництва i експорту, сфер використання ліцензованого вироби;

12) прагнення до міжфірмового співробітництво замість конкуренції [4, с. 154].

Загалом, компанії, які розгорнули 60 і більше відсотків своїх витрат на дослідження і розробки за межами штаб-квартири, отримали премію в розмірі $30 \%$ від операційної маржі та прибутку на активи та $20 \%$ від зростання операційного доходу за рахунок інших конкурентів, орієнтованих на національну економіку. Так, компанії, що застосовують стратегії формування інтелектуального капіталу виграють порівняно 3 компаніями, орієнтованими на національну економіку. 
Висновки та перспективи подальших досліджень. Таким чином, формування інтелектуального капіталу корпорацій включає в себе широкий спектр механізмів, що орієнтовані в першу чергу на формування та забезпечення структурного капіталу, як найбільш ефективного. Існує два ключові механізми залучення інтелектуального капіталу - формування власного та залучення із зовнішніх джерел. Більшість ТНК використовують обидва механізми для максимально ефективного накопичення інтелектуального капіталу та його використання. Перспективами подальших досліджень є обгрунтування можливостей використання досвіду ТНК у вітчизняній практиці.

\section{Список літератури}

1. Быкова А. А. Влияние интеллектуального капитала на результаты деятельности компании [Текст] / А.А. Быкова, М.А. Молодчик // Вестник Санкт-Петербургского университета. Серия 8. Менеджмент. - 2011. - № 1. - С. 27-55.

2. Білошапка В. А. Транснаціональні корпорації в міжнародному бізнесі [Текст] / В.А. Білошапка. Киев: КНЕУ, 2011. - 45 с.

3. Боос В.О. Использование понятия энтропии для описания влияния интеллектуального капитала на финансовые результаты предприятия [Текст] / В. О. Босс // Вестник ЮУрГУ. Серия: Экономика и менеджмент. - 2011. - № 28 (245). - С. 12-16.

4. Брукинг Э. Интеллектуальный капитал: Ключ к успеху в новом тысячелетии [Текст] : пер. с англ. / Э. Брукинг; Ред. Л.Н. Ковалик]. - СПб.: Питер, 2009. - 288 с.

5. Васильев В.С. Американская политика в области науки [Текст] / В.С. Васильев // США - Канада: экономика, политика, культура. - 2010. - №6. - С.20-24.

6. Ветрова Е.Н. Отдельные аспекты управления интеллектуальным капиталом организации / Е.Н. Ветрова, Е.В. Коковина [Электронный ресурс] // Современные проблемы науки и образования. 2011. - № 5. - Режим доступа: http://www.science-education.ru/ru/article/view?id=4836.

7. Гойло В. Интеллектуальный капитал [Текст] / В. Гойло // Международная экономика и международные отношения. - 1998. - №11. - С.68-75.

8. Мазур А.А. Современные инновационные структуры [Текст] / А.А. Мазур, И.Е. Гагауз. - КиевХарьков, 2009. - 312 c.

9. Станис Д.В. Интеллектуальный капитал как фактор развития корпоративных отношений в России [Текст] / Д.В. Станис // Вестник РУДН. Серия: Экономика. - 2005. - № 1. - С. 37-45.

10. Супрун В.А. Интеллектуальный капитал: главный фактор конкурентоспособности экономики в XXI веке [Текст] / В.А. Супрун. - М.: КомКнига, 2006. - 192 с.

11. Школа В.Ю. Управление интеллектуальным капиталом предприятия машиностроительной отрасли [Текст] / В.Ю. Школа, В.А. Щербаченко // Основы ЭУП. - 2013. - № 4(10). - С. 87-91.

12. Corporate R\&D spending hits record highs for the Top 1000, despite concerns of economic protectionism [Електронний ресурс] - Режим доступу: https://www.strategyand.pwc.com/global/home/press/displays/2017-global-innovation1000-study.

13. How much does your country invest in R\&D? [Електронний ресурс] - Режим доступу: http://uis.unesco.org/apps/visualisations/research-and-development-spending/.

14. Laing G. Applying the VAIC model to Australian hotels. Journal of Intellectual Capital [Текст] / Laing G., Dunn J., Lucas S.H. - 2010. - № 11(3). - P. 269-283.

15. Lev B. New Math for a New Economy [Текст] / B. Lev // Fast Company. - 2000. - January-February. 7.

16. Pulic A. VAIC - an accounting tool for IC management [Електронний ресурс] / A. Public - Режим доступу: www.vaic-on.net.

17. The 2017 Global Innovation 1000 study. Investigating trends at the world's 1000 largest corporate R\&D spenders [Електронний ресурс] - Режим доступу: https://www.strategyand.pwc.com/innovation1000.

18. UNESCO SCIENCE REPORT Towards 2030 [Електронний ресурс] - Режим доступу: http://unesdoc.unesco.org/images/0023/002354/235406e.pdf.

\section{References}

1. Bykova, A.A., \& Molodchik, M.A. (2011). Vliyaniye intellektualnogo kapitala na rezultaty deyatelnosti kompanii [The Influence of Intellectual Capital on the Results of the Company's Activities]. Vestnik Sankt-Peterburgskogo universiteta. Seriya 8. Menedzhment - Herald of the St. Petersburg University. Series 8. Management, 1, 27-55 [in Russian].

2. Biloshapka, V.A. (2011). Transnatsionalni korporatsii $v$ mizhnarodnomu biznesi [Transnational 
corporations in the international business]. Kyev: KNEU [in Ukrainian].

3. Boos, V. O. (2011). Ispolzovaniye ponyatiya entropii dlya opisaniya vliyaniya intellektualnogo kapitala na finansovyye rezultaty predpriyatiya [Using the concept of entropy to describe the impact of intellectual capital on the financial performance of an enterprise]. Vestnik YuUrGU. Seriya: Ekonomika $i$ menedzhment. - Herald of SUSU. Series: Economics and Management, 28 (245), 12-16 [in Russian].

4. Bruking, E. (2009). Intellectual Capital: The Key to Success in the New Millennium. L.N. Kovalik (Ed.). SPb.: Piter [in Russian].

5. Vasilyev, V.S. (2010). Amerikanskaya politika v oblasti nauki [American policy in the field of science]. SShA - Kanada: ekonomika. politika. kultura. - USA - Canada: economics, politics, culture, 6, 20-24 [in Russian].

6. Vetrova, E.N., \& Kokovina, E.V. (2011). Otdelnyye aspekty upravleniya intellektualnym kapitalom organizatsii [Some aspects of the organization's intellectual capital management]. Sovremennyye problemy nauki i obrazovaniya. - Modern problems of science and education, 5. Retrived from http://www.scienceeducation.ru/ru/article/view?id=4836 [in Russian].

7. Goylo, V. (1998). Intellektualnyy kapital [Intellectual Capital]. Mezhdunarodnaya ekonomika $i$ mezhdunarodnyye otnosheniya - International Economics and International Relations, 11, 68-75 [in Russian].

8. Mazur, A.A., \& Gagauz, I.E. (2009). Sovremennyye innovatsionnyye struktury [Modern innovative structures]. Kiyev-Kharkov [in Russian].

9. Stanis, D.V. (2005). Intellektualnyy kapital kak faktor razvitiya korporativnykh otnosheniy v Rossii [Intellectual capital as a factor in the development of corporate relations in Russia]. Vestnik RUDN. Seriya: Ekonomika - Bulletin of the Peoples' Friendship University of Russia. Series: The Economy, 1, 37-45 [in Russian].

10. Suprun, V.A. (2005). Intellektualnyy kapital: glavnyy faktor konkurentosposobnosti ekonomiki v KhKhI veke [Intellectual capital: the main factor of the economy's competitiveness in the 21st century]. M.: KomKniga [in Russian].

11. Shkola, V.Yu., \& Shcherbachenko, V.A. (2013). Upravleniye intellektualnym kapitalom predpriyatiya mashinostroitelnoy otrasli [Management of intellectual capital of the enterprise of machine-building branch]. Osnovy EUP - Fundamentals of EHR, 4(10), 87-91 [in Russian].

12. Corporate R\&D spending hits record highs for the Top 1000, despite concerns of economic protectionism. (n.d.). $\quad$ strategyand.pwc.com. Retrieved from https://www.strategyand.pwc.com/global/home/press/displays/2017-global-innovation1000-study [in English].

13. How much does your country invest in R\&D? (n.d.). uis.unesco.org. Retrieved from http://uis.unesco.org/apps/visualisations/research-and-development-spending/ [in English].

14. Laing, G., Dunn, J., \& Lucas, S.H. (2010). Applying the VAIC model to Australian hotels. Journal of Intellectual Capital, 11(3), 269 - 283 [in English].

15. Lev, B. (2000). New Math for a New Economy. Fast Company, 7 [in English].

16. Pulic, A. (n.d.). VAIC - an accounting tool for IC management. vaic-on.net. Retrieved from www.vaicon.net [in English].

17. The 2017 Global Innovation 1000 study. Investigating trends at the world's 1000 largest corporate R\&D spenders. (n.d.). strategyand.pwc.com. Retrieved from https://www.strategyand.pwc.com/innovation 1000 [in English].

18. UNESCO SCIENCE REPORT Towards 2030. (n.d.). unesdoc.unesco.org. Retrieved from http://unesdoc.unesco.org/images/0023/002354/235406e.pdf [in English].

Evelina Panchenko, Postgraduate

SHEE “Kyiv National Economic University Named after Vadym Hetman”, Kyiv, Ukraine

\section{Mechanisms of Formation of Intellectual Capital in the Transnational Corporations}

The modern practices of formation and accumulation of intellectual capital in transnational corporations are summarized. At the current stage of transnational companies' activity, the formation and the most efficient use of intellectual capital is a decisive factor in their long-term competitiveness, sustainable development. Proceeding from the fact that the structure of intellectual capital includes human, structural and organizational capital, we determine the most effective and demonstrative of capital - structural. The structural capital of the corporation includes patent activity and activities, research works, licenses, know-how, etc. The capital itself may be its own, or borrowed from external sources (purchase, lease, free access).

The article defines and analyzes the corporate expenses of the R\&D in the country as well as the share of corporate expenses from the general ones. The volumes and dynamics of financing of transnational corporations of research and development are analyzed. The existing mechanisms of joint participation of corporations in scientific researches, volumes of trade in the results of intellectual activity are highlighted. Factors contributing to the significant dissemination of international strategic alliances, as a form of increasing the intellectual capital of transnational corporations are considered. The advantages and disadvantages of license 
agreements of transnational corporations as an advantageous form of technology transfer and the commercialization of intellectual capital are explored.

It is substantiated that the formation of intellectual capital of corporations includes a wide range of mechanisms, focused primarily on the formation and provision of structural capital, as the most effective. It is determined that there are two key mechanisms for attracting intellectual capital - the formation of own and attracting from external sources. It is proved that most of transnational corporations use both mechanisms to maximize the efficient accumulation of intellectual capital and its using. Prospects for further research are the justification of the possibilities of using the experience of transnational corporations in national practice.

intellectual capital, transnational corporation, research and development (R\&D), royalty, patents, know-how

Одержано (Received) 20.03.2018

Прорецензовано (Reviewed) 22.05.2018

Прийнято до друку (Approved) 28.05.2018

I. О. Царенко, асп.

Центральноукраӥнський національний технічний університет, м. Кропивницький, Україна

\section{Інтегральна оцінка рівня конкурентоспроможності вищої освіти України в умовах переходу до інноваційної моделі економіки: регіональний аспект}

У статті розроблено методичний підхід до інтегральної оцінки рівня конкурентоспроможності вищої освіти на регіональному рівні. Здійснено інтегральне оцінювання конкурентоспроможності вищої освіти за регіонами України, за результатами якого запропоновано диференційовані заходи державного регуляторного впливу, запровадження яких дасть змогу забезпечити подолання існуючих територіальних асиметрій, підвищення ефективності функціонування закладів вищої освіти і конкурентоспроможності вищої освіти в умовах переходу до інноваційної моделі економіки України в цілому.

заклад вищої освіти, заклади вищої освіти, вища освіта, інтегральна оцінка, конкурентоспроможність, державне регулювання.

И. А. Царенко, асп.

Центральноукраинский национальный технический университет, г. Кропивницкий, Украина

Интегральная оценка уровня конкурентоспособности высшего образования Украины в условиях перехода к инновационной модели экономики: региональный аспект

В статье разработан методический подход к интегральной оценки уровня конкурентоспособности высшего образования на региональном уровне. Осуществлена интегральная оценка конкурентоспособности высшего образования по регионам Украины, по результатам которой предложены дифференцированные меры государственного регуляторного влияния, внедрение которых позволит обеспечить преодоление существующих территориальных асимметрий, повышения эффективности функционирования учреждений высшего образования и конкурентоспособности высшего образования в условиях перехода к инновационной модели экономики Украины в целом.

учреждение высшего образования, учреждения высшего образования, высшее образование, интегральная оценка, конкурентоспособность, государственное регулирование

Постановка проблеми. В сучасних умовах трансформаційної перебудови національної економіки загалом та вимог до інтеграції економічної системи у світовий простір особливої уваги зі сторони держави потребує система вищої освіти, адже на етапі дестабілізації усіх сфер суспільно-політичного та фінансово-економічного стану країни, катастрофічного зниження рівня життя, політичної та економічної криз, повсюдного відтоку «мізків» та підвищення міграційних потоків за кордон, сектор третинної освіти стає вкрай важливим, як один із ключових елементів досягнення довгострокових конкурентних переваг країною та каталізатора її подальшого розвитку.

(C) I. О. Царенко, 2018 